\section{Magdalena Jóźwiak}

Uniwersytet Wrocławski

mjozwiak.uni.wr@gmail.com

DOI: http://dx.doi.org/10.12775/BPTh.2017.025
Biblica

et

Patristica

Thoruniensia

10 (2017) 4: 493-507

ISSN (print) 1689-5150

ISSN (online) 2450-7059

\title{
Pseudo-Hieronim. Zwięzły komentarz do Księgi Psalmów, Ps 21 (Breviarium in Psalmos, Ps 21)
}

\section{Pseudo-Jerome: \\ A Concise Commentary on the Book of Psalms, Ps 21 (Breviarium in Psalmos, Ps 21)}

Streszczenie. Celem niniejszego artykułu jest skomentowanie i przetłumaczenie z języka łacińskiego na język polski komentarza do Ps 22 (21) (zob. PL 26, 879 A - 884 C). Praca wydaje się zasadna co najmniej z dwóch powodów. Po pierwsze, Pseudo-Hieronimowy komentarz do wspomnianego psalmu nie doczekał się jeszcze opracowania na gruncie polskim. Po drugie, Ps 22 (21) jest na tyle znany, a nadto cytowany w Nowym Testamencie, że wydaje się, iż warto udostępnić szerszemu gronu ów starożytny komentarz. O autorze Breviarium in Psalmos niewiele wiadomo, poza tym, że starał się w swym komentarzu naśladować metodę egzegetyczną św. Hieronima.

\begin{abstract}
The most important point of this article is to comment and translate from Latin into Polish commentary on Ps 22 (21) (see PL 26, 879 A - 884 C). Work seems worthy of attention, at least for two reasons. First, the Pseudo-Jerome commentary on the said psalm has not yet been translated into Polish. Second, Ps 22 (21) is well known and, moreover, quoted in the New Testament, that it seems worthy to make the ancient commentary worthwhile to the wider public. About the author Breviarium in Psalmos little known, except that he tried to imitate the exegetical method in his commentary of st. Jerome.
\end{abstract}

Słowa kluczowe: Pseudo-Hieronim; Breviarium in Psalmos; Księga Psalmów; Ps 22 (21).

Keywords: Pseudo-Jerome; Breviarium in Psalmos; Psalms; Ps 22 (21).

\section{Wstęp}

Księga Psalmów należy do najbardziej poczytnych ksiąg Pisma Świętego. — Teksty psalmów nie tylko były wykorzystywane w kulcie izraelskim, lecz również w pierwotnym Kościele, co poświadcza sama Biblia (zob. np. 1 Kor 
14,15; Ef 5,19; Kol 3,16). Psalmy, przypisywane tradycyjnie Dawidowi, są zróżnicowane pod względem gatunkowym.

Egzegeci dopatrują się w wielu psalmach proroctw dotyczących osoby Jezusa Chrystusa i takim jest Ps $21^{1}$, a w Biblii Tysiąclecia Ps 22 (21) wskutek różnic występujących w podziale między $\mathrm{BH}$ a starożytnymi tłumaczeniami. Ów psalm jest zaliczany do grupy psalmów mesjańskich, obok 9 innych psalmów: 2, 10, 45, 72, 89, 101, 110, 132, 144.

Ps 21 jest lamentacją, w której nie ma osobnej inwokacji, tj. wołania o pomoc, lecz Psalmista przechodzi od razu do skargi, która tworzy wraz z inwokacją całość w postaci bólu². Jest to pytanie, skierowane do Boga: Boże mój, Boże mój, czemuś mnie opuścit? Słowa te wypowiedziane na krzyżu można uznać za najbardziej znane i najgorzej rozumiane ze wszystkich pytań, wypowiedzianych przez Jezusa podczas jego ziemskiego życia. Z pewnością nie rozumieli ich ci, którzy stali pod krzyżem, sądząc, że woła on Eliasza ${ }^{3}$. Stąd od starożytności Ojcowie Kościoła i pisarze chrześcijańscy uprawiali egzegezę, próbując objaśniać trudne passusy z Pisma Świętego. Komentarze ich są świadectwem nieustannego zmagania się człowieka ze słowem, co w konsekwencji ma ich przybliżyć do Słowa Wcielonego (por. J 1,14).

Takim jest komentarz Pseudo-Hieronima do Księgi Psalmów. Celem najważniejszym niniejszego artykułu jest przetłumaczenie z języka łacińskiego na język polski komentarza do Ps 21. Praca wydaje się zasadna co najmniej z dwóch powodów. Po pierwsze, Pseudo-Hieronimowy komentarz do wspomnianego psalmu nie doczekał się jeszcze opracowania na gruncie polskim. Po drugie, Ps 21 jest na tyle znany, a nadto cytowany w Nowym Testamencie, że wydaje się, że warto udostępnić szerszemu gronu ów starożytny komentarz.

1 Wybrana bibliografia do tego psalmu przedstawia się następująco: D. Adamczyk, Reinterpretacja cytatów $z$ Psalmu 22 w Ewangeliach synoptycznych, s. 52-58; H. Gese, Psalm 22 und das Neue Testament: Der älteste Bericht vom Tode Jesu und die Entstehung des Herrenmahles, s. 1-22; S. Jędrzejewski, Psalm 22 w ewangelicznej interpretacji pasyjnej, s. 197-210; J. Kuc, Ps 22 w świetle metody reinterpretacji, s. 183-191; J. Kuc, Interpretacja mesjańska psalmu 22, s. 5-19; H.D. Lange, The Relationship between Psalm 22 and the Passion Narrative, s. 610-621; L.I.J. Stadelmann, The Passion Narrative in the Synoptics as Structured on Ps 22 (21), s. 193-221; A. Tronina, Chrystologiczna lektura Ps 22, s. 61-68.

2 Por. S. Łach, Księga Psalmów. Wstęp - przekład z oryginału - komentarz - ekskursy, s. 174.

3 To nieporozumienie wydaje się całkowicie uzasadnione, gdyż w języku hebrajskim wyrażenie (Bóg mój) stanowi część składową imienia tego proroka. Nie dziwi więc, że część osób, która słyszała wołanie Jezusa skojarzyła je z prorokiem Eliaszem, który miał powrócić w dniach ostatecznych (por. Ml 3,23). 
O autorze Breviarium in Psalmos niewiele wiadomo, poza tym, że starał się w swym komentarzu naśladować metodę egzegetyczną św. Hieronima, który w swych komentarzach biblijnych przywołuje rozmaite przekłady komentowanego wersu. W zasadzie nie dysponujemy żadnymi konkretnymi informacjami, które pozwoliłyby go umieścić w szerszym kontekście kulturowo-społecznym i pogłębić wiedzę na jego temat. Pomimo tego, iż J. P. Migne w Patrologia Latina umieszcza Breviarium in Psalmos pod imieniem św. Hieronima, to jednak kwestionuje jego autorstwo ${ }^{4}$. Współczesne monografie, traktujące o osobie i spuściźnie autora Wulgaty nie wyliczają w wykazie pism Hieronimowych tego dzieła ${ }^{5}$, stąd przyjmujemy, że autorem nie jest św. Hieronim, lecz któryś z jego naśladowców.

Na koniec kilka uwag dotyczących samego tłumaczenia. Przekładu dokonano na podstawie tekstu wydanego przez J. P. Migne'a ${ }^{6}$. Cytaty biblijne są tłumaczone z tekstu komentarza do Ps 21 . Numeracja poszczególnych wersetów z Biblii jest oparta na tekście Wulgaty.

\section{Przekład z komentarzem}

\section{Wers 2}

Boże, Boże mój, wejrzyj na mnie, dlaczego mnie opuściłeś?

Pan, wisząc na krzyżu, posłużył się tym wersetem ${ }^{7}$. Z czego wnioskujemy, że Pan, będąc na krzyżu, odśpiewał cały [ten] psalm. Zwrotu zaś wejrzyj na mnie, który znajduje się w środku [tego wersu], nie ma w hebrajskich kodeksach, a słowo Pana dowodzi, iż jest to słuszne, gdyż także to w Ewangeliii ${ }^{8}$ pominął, jako że mówi: Dlaczego mnie opuściłeś? Tutaj wypowiada się ludzka natura [Chrystusa], w jaki sposób została opuszczona w Adamie, kiedy [ten] przekroczył zakaz . Albo w czasie męki Chrystus został opuszczony co do ciała. Daleko od zbawienia mojego słowa moich występków. W tym miejscu daleko wypowiada boska natura [Chrystusa]. Słowa moich występków, ponieważ nasze

4 Zob. PL 26, 801-814.

5 Zob. choćby wykaz pism św. Hieronima: J. N. D. Kelly, Hieronim. Życie, pisma, spory, s. $461-462$.

6 PL 26, 879 A - 884 C, Paris 1845.

7 Por. Mk 15,34; Mt 27,46.

${ }^{\mathrm{w}}$ tekście oryginalnym Św. Hieronim użył zdrobnienia: versiculum.

8 Por. Mk 15,34 i Mt 27,46.

9 Por. Rdz 2,16-17. 
grzechy poczytuje za swoje. Albowiem w jego zbawieniu nie ma grzechu, lecz od grzesznika daleko jest zbawienie. Albo inaczej: Daleko od zbawienia mojego słowa moich występków. Akwila ${ }^{10}$ to miejsce w ten sposób zinterpretował: Daleko od zbawienia mojego słowa mego jęku, Symmach ${ }^{11}$ - słowa moich jęków, piąte i szóste wydanie ${ }^{12}$ - słowa mojego wołania. A według pozostałych tłumaczy [ten wers] ma taki sens: Jęki moje i próby, poprzez które usiłowałem zbawić zawsze naród Izraela, stały się dalekimi od mojego zbawienia, które pragnąłem ofiarować [temu] ludowi, ponieważ oni sami nie chcieli przyjąć uzdrowienia. $\mathrm{Z}$ kolei według tłumaczy Septuaginty ${ }^{13}$ [ów passus] ma następujący sens: To, kiedy błagam o zbawienie, kiedy uskarżam się, że ja zostałem opuszczony, nie mówię [tego] z własnej perspektywy, lecz ludu, którego grzechy sam przyjąłem w moim ciele. Stąd mówię: Daleko są od mego zbawienia te słowa, które wydaję [z siebie]. Nie tak bowiem domagam się zbawienia dla siebie, który jestem Bogiem, jak dla ludu, który jest pozbawiony zbawienia.

\section{Wers 3}

Będę wołał za dnia i nie wystuchasz i w nocy, a nie ku mojej głupocie.

Wisząc za dnia, nie jest wysłuchany przez Ojca, nocą jako zwycięzca powstaje z ziemi. Inaczej: Ten w [czasie] radości nie jest wysłuchany, a jest wysłuchany we łzach. Stąd mówi: Nie ku mojej głupocie, to znaczy nie wołałem nada-

10 W swoim przekładzie Akwila (ok. 130 r.) opiera się na „filozofii tłumaczenia” Rabbi Akiby (zm. ok. 135), w myśl której każde słowo, każda litera tekstu hebrajskiego ma swe niezastąpione znaczenie, które należało zachować - w miarę możliwości również w przekładzie.

Akwila w tym wersecie zawarł dokładnie: $\beta \rho v \chi \eta \dot{\mu \alpha} \boldsymbol{\alpha} \boldsymbol{\varsigma} \varsigma \boldsymbol{\mu o v}$, co trzeba byłoby, przekładając na język łaciński, przetłumaczyć jako rugitus mei, a nie gemitus mei, jak uczynił Pseudo-Hieronim. Zatem Akwila omawiany werset zinterpretował w sposób następujący: Daleko od zbawienia mojego słowa ryku mego.

11 Przekład Symmacha pochodzi z końca II w. po Chr., i ze względu na kunsztowność słowa wywiera szczególne wrażenie na Hieronimie, który często korzysta z niego, pracując nad swoim tłumaczeniem Pisma Świętego.

12 Są to greckie tłumaczenia anonimowego autorstwa, które nie zachowały się do naszych czasów. Trudno ustalić, o jakie przekłady dokładnie chodzi. Św. Hieronim, jak i inni komentatorzy Pisma Świętego nazywali je po prostu quinta et sexta editio.

13 Było to zestawienie w 6 kolumnach: hebrajskiego tekstu Pisma Świętego, jego transkrypcji w alfabecie greckim oraz tłumaczeń Akwili, Symmacha, Septuaginty i Teodocjona. Krytyka tekstu podjęta przez Orygenesa polegała na zaznaczeniu w 5 kolumnie (Septuaginta) dodatków lub braków w porównaniu z innymi tłumaczeniami. Do dziś zachowały się tylko nieliczne fragmenty Heksapli. (por. M. Arndt, Heksapla, w: Encyklopedia Katolicka, t. 6, s. 644). 
remno. I Akwila przełożył $\mathrm{z}$ hebrajskiego, odnotowując: I noca i nie będziesz milczał, to znaczy wysłuchasz mnie, odpowiesz mi, sprawisz to, o co się modliłem. Boże mój, będę wołał za dnia i nie wysłuchasz i w nocy. Chrystus wołał na krzyżu i modlił się za swoich: został wysłuchany i nie został wysłuchany. Został wysłuchany co do wybranych, jak na przykład za 8 tysiącami ${ }^{14}$ czy też za tymi $120^{15}$ oraz $500^{16}$ braćmi. I nie został wysłuchany, to znaczy za tymi, którzy nie byli wybrani. Dlatego Ewangelista mówi: Krew jego na nas i na synów naszych (Mt 27,25). Natomiast $d z i e n ́$ jest tutaj rozumiany jako coś dobrego, noc zaś jako coś złego. Albo też dzień i noc, to pomyślność i przeciwności w Kościele. Kościół nie jest wysłuchany w czasie pomyślności, aby się nie wynosił oraz nie jest wysłuchany w czasie przeciwności, aby więcej się oczyszczał. A nie ku mojej głupocie, czyli Syn wiecznie współistniejący z Ojcem wie wszystko, dlaczego nie będzie wysłuchany w dniu męki, to znaczy za synów śmierci oraz pomyślność i ucisk swego Kościoła.

\section{Wers 4}

Ty zaś w świątyni mieszkasz, chwało Izraela.

Głos proroka. W świątyni mieszkasz, to znaczy w swoim ciele, albo w niebie, albo w Kościele.

\section{Wers 5}

W tobie złożyli nadzieję nasi ojcowie, Panie, złożyli nadzieję i wyzwoliłeś ich.

Złożyli nadzieję patriarchowie i prorocy czy też inni i wyzwoliłeś ich, to znaczy z Egiptu albo z Babilonii. Nie zostali zawstydzeni (Ps 21,6), ponieważ, co obiecałeś, to wypełniłeś, czyli [ofiarowałeś] ziemię obiecaną i długie życie.

14 Trudno ustalić, do jakiego wydarzenia nawiązuje tu Pseudo-Hieronim, gdyż żaden z Ewangelistów nie pozostawił perykopy, w której pojawiłaby się ta liczba. Być może chodzi o jeden z cudów rozmnożenia chleba (por. Mk 6,30-44; Mt 14,13-21; Łk 9,12-17 oraz J 6,1-15), gdzie według przekazu biblijnego Jezus nakarmił ok. 5 tysięcy mężczyzn, nie licząc kobiet i dzieci, których liczba zamknęłaby się wówczas w 3 tysiącach. Inna hipoteza, którą można postawić wskazywałaby na pomyłkę komentatora. Wobec tego, że Pseudo-Hieronim w wielu miejscach się myli, a liczba 8 tysięcy występuje w Piśmie Świętym w złożeniach (zob. choćby: Sdz 20,25; Sdz 20,44; 1 Mch 15,13; 1 Krn 29,7), to można wnioskować, iż mógł coś źle odczytać i zamiast $\mathbf{V}$ (wtedy z pewnością byłoby to nawiązanie do cudu rozmnożenia chleba) odczytał VIII.

15 Zob. Dz 1,15.

16 Zob. 1 Kor $15,6$. 
Inaczej: $w$ tobie złożyli nadzieję nasi ojcowie, [to znaczy] doktorzy Kościoła. Nie zostali zawstydzeni, gdyż zawsze jesteś nadzieją ich samych.

\section{Wers 7}

Ja zaś jestem robak, a nie człowiek.

Mówi to z powodu uniżenia [za sprawą] przyjęcia ciała [ludzkiego], Izajasz także podobnie woła: Nie bój się, robaczku Jakubie (Iz 41,14). Hańba ludzi i wzgarda pospólstwa. Jaka jest większa hańba niż krzyż? I wzgarda pospólstwa, to znaczy [Chrystus] został wyszydzony przez lud żydowski. Dlaczego robak, a nie człowiek; podczas gdy mówi w Ewangelii: Syn Człowieczy przyszedł zbawić, co zginęło (Łk 19,10)? Wzmiankuje się, że Chrystus jest robakiem i człowiekiem. Robakiem, gdyż prorok mówi: Nie chciej bać się, robaczku Jakubie (Iz 41,14); a człowiekiem, ponieważ zrodzony z Maryi i porównuje się jego zrodzenie do [narodzenia] robaka, jako że robak, który rodzi się w drzewie nie ma ojca, tylko matkę. I Chrystus zrodził się z Maryi bez [jej] złączenia się z mężczyzną. Bóg uczynił dwa mieszkania: niebo i ziemię. Niebo mieszkaniem aniołów, a ziemię mieszkaniem robaków. Sprawił Bóg, że robak wstępuje do nieba, a anioł [zstępuje] na ziemię. Chrystus poprzez pokorę zstąpił na wszystkich aniołów, a diabeł poprzez pychę został strącony na ziemię. Hańba ludzi i wzgarda pospólstwa: hańba, kiedy Żydzi mówili: Ty bądź [sobie] jego uczniem $(\mathrm{J} 9,28)$, wzgarda, kiedy wypędzili go za miasto i ukrzyżowali go.

\section{Wers 8}

Wszyscy patrzacy na mnie, wyszydzali mnie.

Mówi [to] w odniesieniu do złych [ludzi], podobnie i sami Żydzi wykrzykiwali: Jeśli jesteś Synem Bożym, zejdź z krzyża (Mt 27,40), albo: Witaj, królu Żydów (Mt 27,29). Mówili wargami i potrząsali głową. Mówili wargami, ponieważ co mieli w sercu, to wypowiadali przy pomocy słów. Potrząsali głowa, to znaczy porzucili głowę jedyną, którą jest Chrystus i sprawili sobie liczne głowy demonów.

\section{Wers 9}

Złożył nadzieję w Panu, niech go wyrwie, niech go zbawi, ponieważ miłuje go.

Głos proroka mówi [tutaj] o ludzkiej naturze [Chrystusa]. Złożył nadzieje $w$ Panu, to znaczy ludzka natura w boskiej. Niech go wyrwie, to znaczy od Żydów. Ponieważ miłuje go, czyli Bóg Ojciec zechciał mieć takiego Syna bez 
grzechu, przez którego zgładziłby grzechy świata, o czym mówi prorok: On sam przyjąt nasze choroby i ponióst nasze słabości (Iz 53,4) $)^{17}$.

\section{Wers 10}

Ponieważ ty jesteś [tym], który wyprowadziłeś mnie z łona.

Głos ludzkiej natury [Chrystusa]. Wyprowadziłeś mnie $z$ łona, czyli z łona świętej Maryi albo z Synagogi, ponieważ poprzez przepowiednię proroków został poczęty i przy pomocy wyjaśnienia duchowego, jak gdyby z łona został wyprowadzony. Nadziejo moja od piersi matki mojej itd., to znaczy od piersi Maryi, czyli Chrystus nie wzgardził ssaniem piersi [swej] matki. Albo piersi matki, to Prawo Synagogi. Przekazuje się, że mają dwie piersi, gdyż mają literę i wykładnię [duchową]. Lecz oni sami, to znaczy Żydzi przyjęli jedną pierś, ponieważ przestrzegają tylko wyłącznie litery Prawa. Bogiem moim jesteś ty, nie odstępuj ode mnie (Ps 21,11-12), [to znaczy] w dniu męki.

\section{Wers 12}

Ponieważ ucisk jest blisko.

Jako że sam powiedział: Wstańcie, chodźmy, zbliżył się [ten], który ma zamiar mnie wydać (Mt 26,46). Nie ma [nikogo], kto by wspart, ani anioła ani człowieka, z wyjątkiem ciebie, Ojcze.

\section{Wers 13}

Otoczyły mnie liczne cielce.

Cielce swawolące, to znaczy Żydzi, którzy byli swawolący i niepohamowani.

Otoczyły mnie tłuste byki. Zamiast [słowa] tłuste Symmach przetłumaczył

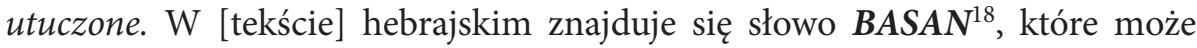
i być przetłumaczone jako_hańba, jako że otoczyli mnie. Przekazuje się, że [są]

17 Zob. także: Mt 8,17.

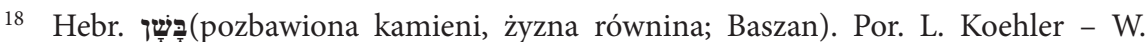
Baumgartner - J.J Stamm, Wielki słownik hebrajsko-polski i aramejsko-polski Starego Testamentu, I, s. 156, nr 1458.

W słowniku języka hebrajskiego nie znajdziemy informacji, że to słowo można tłumaczyć jako hańba. Stąd Pseudo-Hieronim, który najprawdopodobniej nie znał języka hebrajskiego (lub znał słabo alfabet) podaje błędną informację. Oczywiście istnieje słowo podobne do o wyraz שֶּ który właśnie tłumaczy się jako hańba. Por. L. Koehler, W. Baumgartner, J.J. Stamm, Wielki słownik hebrajsko-polski, I, s. 156, nr 1462. 
bykami z powodu swej pychy, to znaczy przywódcy ich Annasz i Kajfasz oraz pozostali. Tłustymi [są] wskutek ociekania nieprawością.

\section{Wers 14}

Otworzyli na mnie usta swoje.

Kiedy mówili: Niech będzie ukrzyżowany ${ }^{19}$. Tak jak lew porywający i ryczacy. To znaczy, kiedy zamyślali o nim, w jaki sposób go zgładzić. Porywający, gdy pojmali go z mieczami i kijami.

\section{Wers 15}

Jestem wylany, tak jak woda i rozproszyły się wszystkie kości moje.

Podobnie Żydzi postanowili wytracić Chrystusa, tak jak wodę, która się zbiera, rozlewa i nie powraca. Rozproszyły się wszystkie kości moje. Podaje się, że Apostołowie są kośćmi Chrystusa, ponieważ tak jak ciało jest podtrzymywane przez kości, tak i ciało Chrystusa, którym jest Kościół ${ }^{20}$ jest umacniane przez Apostołów czy też doktorów [Kościoła].

\section{Stało się serce moje.}

Serce Chrystusa jest rozumiane jako Kościół wcześniej niż Chrystus wstąpił na krzyż, który miał miano [śmierci] okrutnej, gdyż nieliczni podejmowali cierpienie dla imienia jego. Dlatego napisano: Za sprawiedliwego, kto podejmuje się umrzeć? (Rz 5,7). Jak wosk topniejący. Ponieważ, kiedy Chrystus wstąpił na krzyż, później wszyscy święci zaczęli znosić uciski dla niego z powodu nadziei przyszłej zapłaty. W środku wnętrza mojego. To znaczy w środku Kościoła. Stało się serce moje, jak wosk topniejący w środku wnętrza mojego. Mądrość moja, która dawniej nie była znana, rozpalona zapłonęła w ogniu męki i została przyjęta przez Kościół.

\footnotetext{
${ }^{\mathrm{Z}}$ kolei Św. Hieronim w Liber interpretationis hebraicorum nominum (por. PL 23, 776) termin Baszan interpretuje jako pinguis (tłusty, żyzny). Pismo Święte niejednokrotnie sławi żyzność Baszanu (zob. choćby Ps 67,16; Iz 33,9; Jr 50,19), stąd autor Wulgaty i inni tłumacze Biblii nieraz zamiast imienia własnego używają synonimu „tłusty”.

19 Mt 27,23. A także zob. Mk 15,13-14; Łk 23,21-23 i J 19,15.

20 Zob. Ef 1,22-23; Ef 4,15-16; Kol 1,18-19.
} 


\section{Wers 16}

Wyschła, jak skorupa siła moja.

Skorupa zanim zostanie umieszczona w ogniu jest krucha, kiedy zaś umieści się ją w ogniu, to umacnia się. I Chrystus, kiedy tylko wstąpił na belkę krzyża, umocnił swój Kościół. Otóż nie wysechł, jak siano, gdy umarł, lecz jak gdyby skorupa, aby zostać umocnionym. I język mój przysechł do podniebienia mego. Czyli języki Apostołów zaniemówiły w czasie męki, chociaż jeden odezwał się, a mianowicie Piotr, jednak by zaprzeczyć, a nie przyznać się [do Chrystusa ${ }^{21}$. Albowiem uczniowie przestrzegający moich nakazów mówią o mnie do potomności. I doprowadzili mnie do prochu śmierci. To znaczy do Wcielenia albo do piekieł, kiedy stamtąd wyprowadził z sobą dusze świętych. I doprowadzili mnie do prochu śmierci. Mniemali, że ja zostanę obalony w śmierci, tak jak bezbożnicy, których wiatr zmiótł ${ }^{22}$, jak gdybym [ja] nie miał mocy, by zmartwychwstać.

\section{Wers 17}

Ponieważ otoczyly mnie psy mnogie.

Właściwością psów jest to, że dzielą radość ze swym panem i szczekają na rabusia. W tym miejscu psy są odczytywane jako Żydzi, którzy szczekali na Chrystusa i dzielili radość z rabusiem, to znaczy z Barabaszem, kiedy prosili o niego, a Chrystusa zabili ${ }^{23}$. Ponieważ otoczyły mnie psy mnogie, nie mówiące [rzeczy] prawdziwych, lecz szczekające [rzeczy] nikczemne. Zgraja niegodziwców obległa mnie. [To znaczy] zgraja Żydów. Psy mnogie. Zamiast [słowa] psy tekst hebrajski ma $\mathbf{C H E L A B I M}{ }^{24}$, co Akwila i Teodocjon ${ }^{25}$ zinterpretowali jako myśliwi. Zgraja niegodziwców obległa mnie. Żydzi [go] oblegli, to znaczy otoczyli Chrystusa.

\footnotetext{
21 Zob. u Synoptyków: Mk 14,66-72; Mt 26,73-75; Łk 22,55-57 oraz J 18,26-27.

22 Por. Ps 1,4 .

23 Por. Mk 15,6-15; Mt 27,15-26; Łk 23,17-25 i J 18,39.

24 Hebr. כְּלְבְים
}

Jest to kolejny argument na to, że Pseudo-Hieronim nie znał języka hebrajskiego, gdyż właśnie słowo בְּל w w podstawowym znaczeniu tłumaczy się jako „pies”. Por. L. Koehler, W. Baumgartner, J.J Stamm, Wielki słownik hebrajsko-polski, I, s. 448, nr 4156.

25 Tłumaczenie stanowi w dużej mierze przeróbkę wcześniejszego tekstu LXX. Powstało na przełomie I i II w. po Chr., choć ostateczna wersja jest przypisywana Hebrajczykowi Teodocjonowi (ok. 180 r.). 
Przebodli ręce moje i nogi moje.

[W tym wersecie] został użyty czas przeszły zamiast przyszłego. Przebodli, [czyli] przybili gwoździami i odnaleźli wielki owoc, to znaczy zbawienie narodów. I policzyli wszystkie kości moje (Ps 21, 18). Przyglądali się członkom jego rozciągniętym na krzyżu.

\section{Wers 18}

Oni sami zaś przypatrywali się itd.

Mówiąc: Innych wybawiat, a siebie samego nie może wybawić (Mt 27,42).

\section{Wers 19}

Rozdzielili sobie szaty moje.

Dając każdemu żołnierzowi po jego części. I nad suknia moja rzucili los. Rozprawiając o tunice: Nie rozdzierajmy jej, lecz rzućmy o nia losy, do kogo ma należeć (J 19,24). Albo inaczej: Rozdzielili sobie szaty moje i nad sukniq moja rzucili los. Jako że [było] czterech żołnierzy, to uczynili cztery części, a tuniki nie dzielili, [tutaj] wskazał na jedność Kościoła, ponieważ [tunika] nie została rozcięta. Heretycy usiłują ją rozciąć, lecz nie mogą.

\section{Wers 20}

Ty zaś, Panie, nie oddalaj ode mnie wspomożenia twego.

Ludzka natura [Chrystusa] zwraca się do boskiej, aby przyszła jemu z pomocą w czasie męki. Ty zaś, Panie, nie oddalaj ode mnie wspomożenia twego, lecz stale mnie ożywiaj. Wejrzyj ku obronie mojej. Aby właśnie jakaś część niszczycielskiego piekła nie górowała nade mną.

\section{Wers 21}

Wyrwij od włóczni duszę moją.

Wyrwij od miecza albo od nikczemności Żydów. Albo wyrwij duszę moją spod tej władzy, która zwodząc prowadzi do zguby. I $z$ łapy psa jedyna moją. Psy, to Żydzi. Jedyna to dusza Chrystusa. Mówi się jedyna, ponieważ ta dusza jest bez grzechu i inne dusze są oczyszczane przez nią. Albo jedyna to Kościół, a $z$ łapy psa, [czyli] z paszczy piekła, które psim zwyczajem chciwie pożera. 


\section{Wers 22}

Wybaw mnie z paszczy lwa.

Paszcza lwa to naród żydowski z powodu siły jego niegodziwości.

I od rogów jednorożców moja uniżoność. Jednorożec ${ }^{26}$ symbolizuje [tutaj] ten sam naród żydowski, gdyż ma [on] jeden róg, to znaczy jedno Prawo, stąd trąca [tym rogiem] wszystkie narody, by ich wygubić. I od rogów jednorożców moją uniżoność. Od sług szatana, przez których ludzie wynoszą się bardzo w pysze. Do tej pory mówił o męce, teraz o zmartwychwstaniu wspomina, gdyż mówi:

\section{Wers 23}

Będe opowiadat imię twe braciom moim.

Głos Chrystusa. Bracia to Apostołowie, a kiedy zmartwychwstał, on sam powiedział: Idźcie, powiedźcie moim braciom, aby udali się do Galilei, tam mnie zobacza (Mt 28,10). Pośród Kościoła będę cię chwalić. To znaczy w jedności Kościoła pośród ludów wierzących. Będę cię chwalić, [czyli] będę głosił ciebie.

\section{Wers 24}

Którzy boicie się Pana, chwalcie go.

Wszyscy święci, którzy się go boją lękiem świętym, chwalą go. Całe potomstwo Jakuba, niech go wysławia. To znaczy naród młodszy, usuwający grzechy, niech go wysławia. Zwłaszcza potomstwo chrześcijan, któremu będzie służył [naród] starszy ${ }^{27}$.

\section{Wers 25}

Niech sie go boi całe potomstwo Izraela.

To znaczy wszyscy widzący Boga, którzy narodziliście się przez chrzest, widzicie Boga umysłem. Ponieważ nie wzgardził ani nie zlekceważył błagania ubo-

26 Starożytni Grecy i Rzymianie dokładnie rozróżniali dwa stworzenia: jednorożec i nosorożec, czego przykładem są opisy zob. K. Morta, Świat egzotycznych zwierząt u Solinusa, s. 49. 156. Później, ponieważ to samo hebrajskie słowo רְ było tłumaczone jako rhinoceros albo monoceros, to różnica pomiędzy tymi dwoma stworzeniami się zatarła i nastąpiło utożsamienie jednego z drugim zob. Idem, $Z$ badań nad źródłami opisów zwierząt u Solinusa, s. 86, przyp. 23.

27 Tutaj komentator nawiązuje do narodzin Ezawa i Jakuba (por. Rdz 25,19-28). 
giego. [Nie zlekceważył] mojego [błagania], który dla was stałem się ubogim ${ }^{28}$. Albo Bóg nie zlekceważył zastępów chrześcijan, lecz wysłuchał [ich próśb].

Ani nie odwrócił swej twarzy ode mnie.

Lecz przywrócił mnie do życia z [krainy] zmarłych. I gdy wołałem do niego, wystuchał mnie. Odpowiadając: Już wsławiłem i po raz drugi wsławię (J 12,28). Chrystus został wysłuchany w czasie męki, a Kościół w czasie ucisku.

\section{Wers 26}

U ciebie chwała moja w Kościele wielkim.

To znaczy u Ojca, gdyż powiedział: Ja i Ojciec jedno jesteśmy (J 10,30). $U$ ciebie chwała moja $w$ Kościele wielkim, który rozlewa się na całym świecie wskutek wiary. Śluby moje złożę dla Pana wobec bojacych się go. Śluby Chrystusa, to [jego] narodzenie albo też męka, a śluby Kościoła, to dobre uczynki. Albo też ofiarują misterium ciała i krwi mojej z tymi, którzy celebrują je w bojaźni jego $^{29}$.

\section{Wers 27}

Ubodzy będa jedli i się nasyca.

Ubodzy, to Apostołowie, a będa jedli ciało Chrystusa. Będa chwalić Pana [ci], którzy go szukają. Poznając przez wiarę i uczynki, że on sam jest chlebem żywym, który zstąił z nieba (J 6,51).

Serca tych będą żyć na wieki.

Serce, to ich dusza. [Będą żyć] bez końca, ponieważ kto będzie spożywał $\mathrm{z}$ tego chleba, duchowy sens będzie żył w nim na wieki ${ }^{30}$.

\section{Wers 28}

Przypomną sobie i wróca do Pana wszystkie krańce ziemi.

28 Por. 2 Kor 8,9; Flp 2,5-11.

29 W oryginale: Vel mysterium corporis ac sanguinis mei (sic!) offerant cum his qui in ejus timore haec celebrant. W tym miejscu zamiast zaimka dzierżawczego „mój” powinien być użyty jeden z zaimków wskazujących.

30 Por. J 6,52. 
To znaczy uczynił Pan Bóg lud chrześcijański, aby przypominał sobie o nim i zawracał ze swych złych dróg. Całe mnóstwo ludów poznaje na nowo, że są oni okryci ciemnościami, dlatego przystępują [do Pana], aby zostali oświeceni.

I będa [go] adorować przed obliczem jego wszystkie szczepy pogańskie.

I teraz adorują i w przyszłości [będą go adorować], gdyż według [słów] Apostoła zegną się przed nim wszystkie kolana ${ }^{31}$.

\section{Wers 29}

Bo władza królewska należy do Pana i on sam będzie panował nad narodami.

Władza diabła upadła, natomiast władza królewska Chrystusa nadeszła. Kiedy ten wstąpił do nieba, wszystkie [rzeczy] są mu podległe.

\section{Wers 30}

Spożywali i adorowali [go] wszyscy bogacze ziemi.

To znaczy Apostołowie albo pozostali święci spożywali ciało Chrystusa, jak wyżej [autor biblijny] powiedział. Bogacze ziemi, to znaczy [bogaci] w wiarę i uczynki albo cnoty, poznający, że słodki jest Pan (Ps 33,9). Przed obliczem jego upadna wszyscy, którzy zstępują do ziemi. Upadną [na twarz], czyli grzesznicy w dniu sądu wstawią się przed obliczem Boga. Odstępują od pychy świata, aby [go] adorować w uczuciu czystej pokory.

\section{Wers 31}

Dusza moja będzie żyła dla niego, a potomstwo moje będzie służyć jemu samemu.

Kościół, który nie żyje już dla siebie samego, lecz Chrystus w nim żyje. Albo inaczej: Dusza moja będzie żyła dla niego, a potomstwo moje będzie służyć jemu samemu. Dusza Chrystusa żyje w Bogu Ojcu, a śmierć nie będzie więcej panować nad nim $(\mathrm{Rz}$ 6,9). Albo Kościół będzie żyć w Chrystusie. Potomstwo moje to synowie Kościoła, a będzie służyć jemu samemu - lud wierzących.

\section{Wers 32}

Będzie opowiadane Panu przyszłe pokolenie. 
Prorok wspomina przyszłe pokolenie, czyli naród pogan, którzy istnieli zanim Chrystus przyszedł na świat, aby [ludzie] uwierzyli w niego. Albo przyszłe pokolenie to jest cały, nienaruszony blask na dzień sądu. Ogłosza niebiosa sprawiedliwość jego. To znaczy Apostołowie albo doktorzy [Kościoła]. Sprawiedliwość jego. Czyli przykazania jego. Ludowi, który się narodzi. To znaczy przez słowo głoszenia [Dobrej Nowiny]. Który uczynił Pan. Czyli wybrał przed wiekami. Ludowi, który się narodzi, który uczynił Pan. Który przybliżając się poprzez wiarę, przez chrzest narodził się na nowo w Chrystusie. Ten uznał za [rzecz] godną wyróżnić nas, abyśmy mieli przed obliczem naszym jego rany i z Tomaszem ${ }^{32}$ dotykamy śladu po gwoździach jego albo łączyłbym to z pamiętającymi o całkowitym uniżeniu [w czasie] męki jego, gdy bowiem wzdychając wspominają, że on za nasze grzechy przekroczył [bramy] piekieł, co zawsze powinniśmy czynić [będąc] w tym ziemskim ciele, abyśmy zasłużyli na zjednoczenie się z nim w królestwie. Amen.

\section{Bibliografia}

\section{Tekst źródłowy}

Pseudo-Hieronim, Breviarium in Psalmos, Ps 21, ed. J. P. Migne, PL 26, 879 A - 884 C, Paris 1845.

\section{Opracowania}

Adamczyk D., Reinterpretacja cytatów z Psalmu 22 w Ewangeliach synoptycznych, Zeszyty Formacji Katechetów 9/2 (2009), s. 52-58.

Gese H., Psalm 22 und das Neue Testament: Der älteste Bericht vom Tode Jesu und die Entstehung des Herrenmahles, Zeitschrift für Theologie und Kirche 65 (1968), s. $1-22$.

Jędrzejewski S., Psalm 22 w ewangelicznej interpretacji pasyjnej, Ruch Biblijny i Liturgiczny 65/3 (2012), s. 197-210.

Kelly J.N.D., Hieronim. Życie, pisma, spory, tłum. R. Wiśniewski, Warszawa 2003.

Kuc J., Ps 22 w świetle metody reinterpretacji, w: Mesjasz w biblijnej historii zbawienia, red. S. Łach, M. Filipiak, Lublin 1974, s. 183-191.

Kuc J., Interpretacja mesjańska psalmu 22, Roczniki Teologiczno-Kanoniczne 18/1 (1971), s. 5-19.

Lange H.D., The Relationship between Psalm 22 and the Passion Narrative, Concordia Theological Monthly 43 (1972), s. 610-621. 
Łach S., Księga Psalmów. Wstęp - przekład z oryginału - komentarz - ekskursy, Poznań 1990.

Morta K., Świat egzotycznych zwierząt u Solinusa, Wrocław 2004.

Morta K., Z badań nad źródłami opisów zwierząt u Solinusa, Classica Wratislaviensia 27, Wrocław 2007, s. 77-88.

Stadelmann L.I.J., The Passion Narrative in the Synoptics as Structured on Ps 22 (21), Perspectiva Teológica 15 (1983), s. 193-221.

Tronina A, Chrystologiczna lektura Ps 22, Roczniki Teologiczne 40/1 (1993), s. 61-68.

\section{Słowniki i encyklopedie}

Arndt M., Heksapla, w: Encyklopedia katolicka, red. J. Walkusz, Lublin 1993, t. 6, s. 644. Koehler L., Baumgartner W., Stamm J.J., Wielki słownik hebrajsko-polski i aramejsko-polski Starego Testamentu, red. wyd. pol. P. Dec, I-II, Warszawa 2008. 